\title{
A short implantátumok alkalmazásának tapasztalatai az irodalomban
}

\author{
DR. VAJDOVICH ISTVÁN* DR. OROSZ MIHÁLY**
}

\begin{abstract}
Az irodalomban és a napi fogorvosi praxisban is egyre többet találkozhatunk a short implantátumok alkalmazásával. A témával foglalkozó nemzetközi publikációk száma jelentősen megnőtt az elmúlt években. Mivel az alkalmazással kapcsolatban nagyon sok a vitatott kérdés, a szerzők célul túzték ki, hogy az irodalomban fellelhető publikációk legfontosabb tapasztalatait bemutassák a téma iránt érdeklődő, a dentális implantológiát művelő kollégák számára. A 33 közlemény (melyből 9 review, 24 clinical study) eredményei alapján, a megfelelő indikációk és kontraindikációk figyelembevételével a szerzők a short implantátumok alkalmazására a napi fogorvosi-implantológiai praxisban is lehetőséget látnak és azt javasolják.
\end{abstract}

Kulcsszavak: short implantátum, indikáció, kontraindikáció, alkalmazási alapelvek

A dentális implantológia elmúlt harmincéves története során több alkalommal is láttunk megdőlni sokszor dogmaként tisztelt alapvetéseket. Elég, ha csak a késői terhelés, korai terhelés, azonnali terhelés kérdéseire gondolunk. Ugyanilyen fontos alapszabálynak tartottuk a hosszú távú sikeresség szempontjából a kellően hosszú (min. $10 \mathrm{~mm}$ hosszú, ún. standard méretű) és megfelelően széles átmérőjű (kb. $4 \mathrm{~mm}$ ), illetve nagy felszínű implantátumok alkalmazását is. Nem beszélve a protetikai szempontból fontos ún. implantátumtestrész-felépítmény közötti arányról. Ennek az Implantátum/Koronahossz (I/C) aránynak min. 1-nek kell lennie ahhoz, hogy az implantátum rágóerők általi terhelése hosszú távon is megfelelő legyen.

Tempora mutantur - változnak az idők és mi is, illetve a dentális implantológia alkalmazásával kapcsolatos elveink is folyamatosan változnak az újabb és újabb vizsgálatok alapján. Ezt láthatjuk a short implantátumokkal kapcsolatban is. Az egyre szaporodó tudományos vizsgálatok és hosszú távú klinikai kipróbálás eredményei cáfolják korábbi felfogásunkat, mert irodalmi adatok szerint a short implantátumok alkalmazása egyre inkább elfogadott a mindennapi fogorvosi praxisban is.

A dentális implantológiában használatos short implantátumokkal kapcsolatos eredmények, elvek bemutatását fontosnak tartjuk a kollégák számára. Ezért a nemzetközi tudományos irodalom alapján a short implantátumokkal kapcsolatos, tudományosan kellően megalapozott és a hosszú távú klinikai kipróbálás során igazolt eredményeket ezen áttekintő, összegző közleményben (review) mutatjuk be.

\section{Vizsgálati anyag és módszer}

2014. szept. 22. napján MEDLINE (PUB MED and Ovid), illetve Cohrane adatbázist használtunk a vizsgálandó angol nyelvű közlemények kiválasztásához. A keresőszavak a „short dental implants success” (209 db), „short dental review” (195 db), a „short dental clinical study” (357 db) voltak. Szelekció után 33 közleményt vizsgáltunk, ebből 9 review, 24 pedig clinical study volt. A szelekció szempontjai: a követéses vizsgálat időtartama; a vizsgálatban résztvevők száma; a folyóirat impactfaktora; van-e egyéb (pl. szövettani, mikrobiológiai) vizsgálati eredmény a dolgozatban.

Az implantátumok hossza mindegyik közleményben kevesebb, maximum 10 mm volt. Emellett kritériumnak tekintettük, hogy az állcsontok poszterior régiójában az állcsontgerinc sorvadása miatt $10 \mathrm{~mm}$-nél hosszabb implantátumot kiegészítő sebészi beavatkozás nélkül nem lehetett volna beültetni. A legtöbb közleményben a szerzők „short implantátum” alatt az 5 és 10 mm közötti testhosszúságú implantátumokat értették [3, 20]. Mások short implantátumnak csak a $8 \mathrm{~mm}$-nél rövidebb implantátumokat tekintették [26, 30].

\section{1. Általános értékelés a publikációk alapján}

Az első short implantátumot (7 mm) 1977-ben a Brånemark iskola alkalmazta. [31]

A short implantátumok beültetésének elfogadottsága az elmúlt néhány évben alakult ki. A korábbi években a short implantátumok megítélésekor az alacsony sikerességét és a megjósolhatatlan idejü bennmaradását kifogásolták. Alaptörvényként elfogadtuk, hogy csak 
a hosszabb (standard) implantátumok hozhatnak sikeres időtálló eredményeket. A short implantátumok beültetésével kapcsolatos, statisztikailag igazolt alacsony sikerességről ebben az időszakban számosan beszámoltak [21, 33]. Ezzel szemben jelenlegi éveinkben egyre több közleményben számolnak be a szerzők a short implantátumok beültetésével elért figyelemre méltó sikeres eredményekről [3, 16, 17, 18, 19, 25, 28].

A short implantátumok beültetésének célja elsősorban az állcsontok premoláris/moláris fogak rövid vagy több fogra kiterjedő hiánya esetében rögzített fogpótlások készítése.

A short implantátumok beültetése előtt a szerzők szükségesnek tartják a kezelési terv elkészítéséhez az alábbiakat [18, 31]:

A beültetés javallatai:

- 18 év fölött

- a páciens általános egészségi állapota és a szájhigiéne foka megfelelő

- a parodoncium gyulladásmentes

- a fogak elvesztésének feltehető oka (krónikus vagy agresszív periodontitis, caries stb.)

- parafunkció nincs

- az állcsontgerinc leépülése miatt az adott szituációban legfeljebb csak $8 \mathrm{~mm}$ hosszúságú implantátum ültethető be

- az utolsó extrakció óta legalább 6 hét telt el

- az antagonista fogsorban az okkluzális felszín megtartott.

A short implantátumok beültetését kizáró leggyakoribb okok:

- hiányos vagy elhanyagolt szájhigiéne

- akut, illetve agresszív parodontitis vagy más gyulladásos eredetű betegség

- insufficiens csontmennyiség az implantátum helyének megfelelően, azaz a $8 \mathrm{~mm}$ testhosszúságú implantátum befogadására sincs elegendő csontkínálat
- az implantátum helyének megfelelően korábban csontpótlás történt

- kontrollálatlan diabetes mellitus

- szisztémás immunbetegségek

- dohányzás.

\section{A közlemények részletes értékelése}

Az implantátumok sikerességét a szerzők az Albrektsson \& Zarb-féle (1998) [2] ismérvek alapján bírálták el.

Az átfogó, összefoglaló közlemények két fő csoportba sorolhatók:

1. kezelési eredmények bemutatása (review-k)

2. a sikerességet befolyásoló faktorok ismertetése (study-k).

\subsection{A short implantátumok beültetésével elért eredmények részletes bemutatása néhány fontosabb közlemény alapján.}

Balevi B [4] összefoglaló közleményében a rövid és a standard méretǔ implantátumok sikerességét 1 évvel a fogpótlások viselése után 54 db közleményben közölt eredmények alapján metaanalizis alkalmazásával értékelte, hasonlította össze. Ennek során 14158 standard, illetve 2223 short implantátum eredményeit értékelte. Statisztikailag a terhelés kezdete után a short implantátumok jobb eredményeket mutattak az első év végén, mint a standard implantátumok.

A subgroups elemzések alapján a maxilla poszterior területébe ültetett short implantátumok esetében statisztikailag rosszabb eredményességet talált, mint a standard implantátumoknál, ellenben a mandibula poszterior területébe és a maxilla anterior területébe ültetett implantátumok sikeressége között nem volt különbség. Ezen kívül a szerző nem talált összefüggést a mikroporózus felszínú implantátumok esetében az átmérő és a sikertelenség között.

Tutak M és mtsai [31] által közölt review-ban 32 közleményben 5643 short implantátum beültetésével kap-

1. táblázat

A short implantátumok alkalmazásának jellemzői és a sikerességi mutatók a nemzetközi irodalomban

\begin{tabular}{|l|c|c|c|c|l|}
\hline Szerzők & impl-ok száma & impl-ok mérete & $\begin{array}{c}\text { vizsgálat } \\
\text { idótartama } \\
\text { (a terhelés után) }\end{array}$ & $\begin{array}{c}\text { kumulativ } \\
\text { sikerességi } \\
\text { ráta }\end{array}$ & $\begin{array}{c}\text { közlemények típusa, } \\
\text { száma }\end{array}$ \\
\hline Mangano FC és mtsai [18] & 215 & $3,3-4,1-4,8 \times 8 \mathrm{~mm}$ & $1-10$ év & $95,9 \%$ & study \\
\hline Tutak M és mtsai [31] & 5643 & $5-10 \mathrm{~mm}$ & $1-8$ év & $83,7-100 \%$ & study (13) review (6) \\
\hline Balevi B [4] & 2223 & $7<10 \mathrm{~mm}$ & 1 év & $97,5-98,7 \%$ & review (14) study (40) \\
\hline Lops D és mtsai [16] & 257 & $8 \mathrm{~mm}$ & $10-20$ év & $92,3 \%$ & study \\
\hline Annibali S és mtsai [3] & 6193 & $<10 \mathrm{~mm}$ & 3,2 év & $99,1 \%$ & review (2) study (14) \\
\hline Urdaneta RA és mtsai [32] & 410 & $5 \times 5,05 \times 6,0-5,0$ & 20 hónap & $97,5 \%$ & study \\
\hline Rossi F és mtsai [27] & 40 & $4,1-4,8 \times 6 \mathrm{~mm}$ & 2 & $95 \%$ & study \\
\hline Tellemann G és mtsai [30] & 2611 & $5-9,5 \mathrm{~mm}$ & $1980-2009$ & $93,1-98,6$ & review study (29) \\
\hline Malo P és mtsai [17] & 408 & $7-8,5 \mathrm{~mm}$ & $1-9$ év & $96,2-97,1$ & study \\
\hline Misch CE és mtsai [19] & 745 & $<10 \mathrm{~mm}$ & 6 év & $98,9 \%$ & study \\
\hline
\end{tabular}


csolatos eredmények láthatók. A short implantátumok beültetésére a fő javaslat az alsó és felső állcsont poszterior területe volt. A közleményekben az implantátumok sikeressége 83,7 és $100 \%$ között mozgott. 13 közleményben meghaladta a 95\%-t.

A legalacsonyabb sikerességről Deporter és mtsai [10] számoltak be, akik $5 \mathrm{~mm}$ hosszúságú, porózus felszínú implantátumokat ültettek be maxilla poszterior területeibe. Az eredmények azt mutatták, hogy az ilyen implantátumok kritikus méretüek voltak a hosszú távú sikeresség szempontjából, alkalmazásuk nem javasolható.

Lops D és mtsai [16] 127 beteg $257 \mathrm{db}$ beültetett implantátumát (108 db short; $149 \mathrm{db}$ standard) 10-20 év között követték nyomon. 20 év után a kumulatív túlélési ráta 92,3, illetve 95,9\%-nak bizonyult, míg a kumulatív sikerességi ráta 78,3, illetve 81,4\%-t tett ki. A különbség statisztikailag nem volt szignifikáns. Emellett azt is bizonyította, hogy az állcsontok poszterior területébe ültetett short implantátumok és az anterior területébe ültetett short implantátumok sikeressége azonos valószínűséget mutat. A vizsgált 20 év alatt a periimplantáris csontleépülés átlagértéke a short implantátum esetében 1,8 mm, míg a standard implantátumok mellett 1,9 mm volt. A tasakmélység vizsgálata során nagyobb mint $3 \mathrm{~mm}$ mértéket a short implantátumok mellett 4 esetben, a standard implantátumok mellett 5 esetben találtak.

Mangano FG és mtsai [18] az állcsontok poszterior területén lévő rövid sorközi hiányok (egy vagy két fog területére kiterjedő foghiányok) esetében 194 páciensnek 215 db short implantátumot ültettek be. A 10 évig tartó klinikai utánkövetési idő alatt a szóló koronákat viselő implantátumok 98,5\%-os kumulatív túlélési rátát mutattak. Ugyanakkor a sikerességi ráta ugyanenynyi időszak alatt 95,9\%-nak bizonyult. A beültetésekhez $8 \mathrm{~mm}$ testhosszúságú, különböző átmérőjű implantátumot alkalmaztak. A beültetés után a csontos rögzülésre az alsó állcsontban 3, a maxillában 4-6 hónapot várakoztak, a fogpótlás csak ezután készült el. A beültetéseket kétszakaszos mútéti módszerrel végezték. Az implantátum-fészek kialakításához a menetfúró használatát nem javasolják.

Annibali S és mtsai [3] szerint a short implantátumok alkalmazása a poszterior állcsontok protetikai rehabilitációjában számos előnnyel jár mind a páciensek, mind a fogorvosok számára. Csökken a csontpótlás szükségessége, továbbá a sebészi beavatkozás rizikója a szinusz eleváció mútéte során; kisebb a n.alv. inf. paresztézia esélye, általában is csökken a sebészi beavatkozások veszélye [3, 20, 30]. A dolgozat erőssége a nagyszámú beültetés, gyengéje a viszonylag rövid követési idő.

\subsection{A short implantátumok eredményességét befolyásoló legfontosabb tényezők a közlemények alapján}

Lops D és mtsai [16] vizsgálatai szerint a short implantátumok hosszú távú sikeressége szempontjából a csont minősége, a sebészi technika, az implantátum felszíné- nek mikrostruktúrája, a csontfelszín-implantátum-távolság, a parafunkció és az implantátum primer stabilitása tűnik jelentős befolyásoló tényezőnek, mellyel több szerző is egyetért [5, 12, 14, 19].

Jaffin RA és Berman CL [12] szerint az implantátum hossza direkt módon befolyásolja a sikerességet. Más szerzők szerint [1, 24] a 8 mm testhosszúságú implantátum alkalmazása az ideális. Ugyanis számos szerző ültetett be $6 \mathrm{~mm}$ testhosszúságú short implantátumokat, amelyek nem tekinthetők a hosszú távú sikeresség szempontjából validálhatónak [27, 30, 31]. Szerintük is a $8 \mathrm{~mm}$ testhosszúságú, megfelelő átmérőjű short implantátum a „standard”. Az állcsont minősége befolyásolja a terápia sikerét [22] és a hosszú távú prognózist. A felső állcsont poszterior területén III-IV típusú a csontminőség, itt emiatt a beültetések sikeressége szignifikánsan alacsonyabb [6]. Mások ennek ellenkezőjét találták retrospektív vizsgálataikban, szerintük hasonló sikeresség érhető el a mindkét állcsont poszterior területeibe ültetett short implantátumokkal [16, 17]. Mangano FG és mtsai [18] 1-10 évig tartó retrospektív vizsgálatukban úgy találták, hogy a mikroporózus felszínü, az interface-n a kúposan záródó (locking-taper) kialakítású short implantátumok több vonatkozásban jobbak a mikroporózus felszínú standard $\geq 10 \mathrm{~mm}$ méretű implantátumoknál.

A hosszú távú sikerességet befolyásoló biológiai faktorok közül elsősorban a csont denzitása és a dohányzás túnik a legfontosabbnak [30]. A mandibulában jobb a prognózis, mint a maxillában [25, 26, 28]. Mangano és mtsai [18] a dohányosok esetében (> 15 szál/nap) sem találtak szignifikáns különbséget a túlélési rátában.

A short implantátumok sikerességét is befolyásoló protetikai faktorok közül - egyes szerzők szerint a nagyobb implantátum/korona-arány (az ún. I/C ratio) nem befolyásolja a hosszú távú sikerességet [6, 7, 32]. A felépítmények összesínezése csökkenti az egyes implantátumokra jutó rágónyomást, ezért azt javasolják $[18,19,32]$.

A protetikai faktorok hibáját Jung és mtsai [13] irodalmi adatokat áttekintve a 10 mm-es standard implantátumok esetében 8,8\%-ban a fejrészt rögzítő csavar meglazulásában, 4,1\%-ban a retenció elvesztésében, 3,5\%ban a porcelánfelszín törésében látták 5 év viselése után. Ezzel szemben Lops és mtsai [16] 10 év után a fogpótlásból eredő komplikációk arányát 1,4\%-nak találták. Ezt a jó eredményt a szerzők elsősorban a lockingtaper szisztémájának tulajdonítják. Ez az önzáródó (self-locking) rögzülés az implantátum testrész-fejrész közötti interface-n biztonságos mechanikai stabilitást ad, ami képes ellenállni az excentrikus terhelésnek is. Amellett képes ellenállni a rágás közben fellépő, a felépítményre ható forgatónyomatéknak, ezzel lényegesen csökkentve a protetikai sérülékenységet is [8, 18, 32].

A mozsárszerü kúpos (morse taper) implantátumabutment-kapcsolat előnye, hogy meggátolja a baktériumok megtelepedését az interface-n. Ismert, hogy a csavarral rögzülő fejrészek mellett lévő mikrorésekben 
(40-100 $\mu \mathrm{m}$ ) tartósan fennmaradnak a baktériumtelepek, amelyek nagyban felelősek a periimplantáris gyulladás kialakulásáért, illetve a periimplantáris csont leépüléséért [9, 23].

A locking taper-interface-n az előbiekkel szemben a mikrorés dimenziója mindössze 1-3 $\mu \mathrm{m}$ lehet, amely gyakorlatilag kizárja a baktériumok megtelepedését az interface-n [11]. Mangano és mtsai [18] $215 \mathrm{db}$ short implantátum 10 éves prospektív vizsgálata során ennek tudják be, hogy a DiB (Distance implant to Bone; az implantátum válla és az alveoláris gerinc távolsága, ami a csontleépülés mértékére utal) átlaga 10 év után is csupán 0,62 mm-t tett ki. 2 esetben láttak biológai komplikációt.

Számos klinikus - implantológus - számára nem elfogadható a megszokottnál kisebb I/C arány, ezért nem alkalmaznak short implantátumot. Ezzel szemben Tawil és mtsai [29] úgy találták, hogy ha ez az arány kisebb lesz, akkor sem nő a biomechanikai rizikó, azaz nem okoz periimplantáris csontleépülést. Ugyanez a véleménye több más szerzőnek is [6,7]. Ezzel szemben Bidez és Misch [5] azt javasolják, hogy ha a short implantátumra készülő fogpótlás magassága 10 és $20 \mathrm{~mm}$ közé esik, az implantátumra ható erők nagysága akár $100 \%-k a l$ is nőhet, ezért szükséges egy helyett $2 \mathrm{db}$ implantátum beültetése.

A fenti mechanikai faktorok figyelembevétele mellett nagyon fontos a biológiai szempontok betartása is, elsősorban a biológiai szélesség helyreállítása [18].

\section{Összefoglalás és javaslat az irodalom tükrében}

A nemzetközi irodalomban a short implantátumok alkalmazásával kapcsolatos tudományos közlemények, review-k elemzése alapján jelenleg az alábbi fontosabb megállapításokat tehetjük:

- short implantátumok beültetése a befogadó csont hiánya esetén rövidíti a kezelés idejét, egyszerúsíti a sebészi beavatkozást és csökkenti a komplikáltabb periimplantáris procedúrát. Ezek a tények a pácienseknek kisebb diszkomfort érzést okoznak, és a beavatkozás költsége is kisebb lesz.

- a minimum 7 mm testhosszúságú, mikroporózus felszínú és lehetőleg morse-taper implantátum-abutment rögzülésú short implantátumok széles körben tudományosan igazoltan hosszú távú sikerességet bizonyítottak. A protetikai felépítmények készítése gondos, a körülményeket figyelembe vevő mérlegelést igényel.

- a vizsgált közlések többségében a mandibula poszterior területébe ültetett short implantátumok sikeresebbeknek bizonyultak, mint a maxilla hátsó területein. A mikrostrukturált felszínű short implantátumok jobb eredményt adtak, mint a nyers (machined) felszínú implantátumok.

- a nemzetközi irodalomban közölt eredmények igazolják, hogy a short implantátumok sikeressége lénye- gében megegyező a standard implantátumok sikerességével. Short implantátumok indikációja esetén törekedni kell nagyobb átmérőjü implantátumok alkalmazására.

Fenti eredmények alapján a megfelelő indikációjú short implantátumok alkalmazásával a napi fogorvosi - implantológiai - praxisban hazánkban is egyre inkább számolni kell. A nemzetközi irodalomban közölt tapasztalatok figyelembevételével javasolt, hogy a szakmai fórumok (Szakmai Kollégium, Implantológiai és Protetikai Társaság stb.) részletes szakmai ajánlásokat fogalmazzanak meg a gyakorló fogorvosok számára a short implantátumok alkalmazásával kapcsolatban.

\section{Irodalom}

1. Акс̧а K, IPLIKÇıoglu H: Finite element stress analysis of the effect of short implant usage in place of cantilever extensions in mandibular posterior edentulism. J Oral Rehab 2002; 29: 350-356.

2. AlBREKTSSON T, ZARB GA: Determinants of correct clinical reporting. J Prosthodont 1998; 11: 517-521.

3. Annibali S, Cristalli MP, Dell'Aquila D, Bignozzi I, La Monaca G, PILLONI A: Short dental implants: a systematic review. J Dent Res 2012; 9: 25-32.

4. BALEVI B: In selected sites, short, rough-surfaced dental implants: a critical summary are as successful as long dental implants: a critical summary of Pommer B, Frantal S, Posch M, Watzek G, Tepper G: Impact of dental implants lenght on early failure rates: a meta-analysis of observational studies. J Clin Periodontol2011; 38: 856-863.

5. BIDEZ MW, MisCH CE: Force transfer in implant dentistry: Basic concepts and principles. J Oral Implant 1992; 18: 264-274.

6. Bird H, Schulte J, Kovacs A, Weed M, Chuang SK: Crown-toimplants ratios of short-length implants. J Oral Implant 2010; 36: 425-433.

7. Blanes RJ: To what extent does the crown-implant ratio affect the survival and complications of implant-supported reconstructions? A systematic review. Clin Oral Implant Res 2009; 20: 67-72.

8. BOZKAYA D, MufTu S: Mechanics of the tapered interference fit in dental implants. J Biomechanics 2003; 36: 1649-1658.

9. Broggini N, Mc Manus LM, Hermann JS, Medina RU, Oats TW, SCHENK RK ÉS MTSAI: Persistent acute inflammation at the implantabutment interface. J Dent Res 2003; 82: 232-237.

10. Deporter D, Ogiso B, Sohn DS: Ultrashort sintered porous-surfaced dental implants used to replace posterior teeth. J Periodontol 2008; 79: 1280-1286.

11. Dibart S, Warbington M, Su MF, Skobe Z: In vitro evaluation of the implant-abutment bacterial seal: the locking-taper system. Int J Oral Maxillofac Impl 2005; 20: 732-737.

12. JafFin RA, BERmAn CL: The excessive loss of Branemark fixtures in type IV bone: a 5-year analysis. J Periodontol 1991; 62: 2-4.

13. Jung R, Zembic A, PJetursson BE, Zwalen M, Thoma D: Systematic review of the survival rate and the incidence of biological, technical and aesthetic complications of single crowns on implants reported in longitudional studies with a mean follow-up of 5 years. Clin Oral Impl Res 2012; 23: 2-21.

14. Kotsovilis S, Fourmousis I, Karoussis IK, Bamia C: A systematic review and meta - analysis on the effect of implants lenght on the survival of rough-surface dental implants. J Periodontol 2009; 80: 1700-1718.

15. Lee HI, Frias V, Lee KV, Wright RF: Effect of implant size and shape on implant success rates: a literatur review. J Prosth Dent 2005; 94: 377-381.

16. Lops D, Bressan E, Pisoni I, Cea N, Corazza B, Romeo E: Short 
Implants in Partially Edentulous Maxillae and Mandibles: A 1020 Years Retrospective Evaluation. Int J Dent 2012; ID 351793.

17. Malo P, de Araujo Nobre M, Rangert B: Short implant placed one-stage in maxillae and mandibles: a retrospective clinical study 1 to 9 years of follow-up. Clin Implant Dent Relat Res 2007; 1: 15-21.

18. Mangano FG, Shibli Ja, Sammonds RL, Iaculli F, Piatelli A, ManGANO C: Short $(8 \mathrm{~mm})$ locking-taper implants supporting single crowns in posterior region: 1-to 10-years of follow-up. Clin Oral Impl Res 2014; 25: 933-940.

19. Misch Ce, Steigenga J, Barboza E, Miesch-Dietsh F, Cianciola J: Short dental implants in posterior partial edentulism: a multicenter retrospectic 6-year case series study. J Periodontol 2006; 77: 1340-1347.

20. Monje A, Chan HI, Fu JH, Suarez F, Galindo-Moreno P, Wang HL: Are short dental implants $(<10 \mathrm{~mm})$ effective? A meta-analysis on prospective clinical trial. J Periodontol 2012; 10: 1902.

21. NaERT I, Kautsikakis G, DuYck I: Biologic outcome of implant-supported restorations in the treatment of partial edentulism. Part I. a longitudinal clinical evaluation. Clin Oral Impl Res 2002; 13: 381-389.

22. das Neves FD, Fones D, Bernandes SR, do Prado CJ, Neto AJ: Short implants - An analysis of longitudinal studies. Int J Oral Maxillofac Implants 2006; 21: 86-93.

23. Piatelli A, Vrespa G, Petrone G, Leezzi G, Annibali S, Scarano A: Role of the microgap between implant and abutment: a retrospective histologic evaluation in monkeys. J Periodontol 2003; 74: 346-352.

24. Pierrisnard L, Renouard F, Renault P, Batquinis M: Influence if implants lenght bicortical anchorage on implant stress distribution. Clin Impl Dent Relat Res 2003; 5: 254-262.
25. Pommer B, Frantal S, Willer J, Posch M, Watzek G, Tepper G: Impact of dental implant lenght on early failure rates: a metaanalysis of observational studies. J Clin Periodontol 2011; 38: 856-863.

26. Renouard F, Nisand D: Impact of implants lenght and diameter on survival rates. Clin Oral Impl Res 2006; 17: 35-51.

27. Rossi F, Ricci E, Marchetti C, Lang NP, Botticelli D: Early loading of single crowns supported by $6 \mathrm{~mm}$ long implants with a moderatly rough surface: a prospectiv 2-years follow-up cohort study. Clin Oral Impl Res 2010; 21: 937-943.

28. Sun HL, Huang $C, W u$ YR, SHI B: Failure rates of the short $(<10 \mathrm{~mm})$ dental implants and factors influencing their failure: a systematic review. Int J Oral Maxillofac Implants 2011; 26: 816-825.

29. TaWiL G, Aboujoude N, Younan R: Influence of prosthetic parameters on the survival and complication rates of short implants. Int J Oral Maxillofac Impl 2006; 21: 275-282.

30. Tellemann G, Raghoebar GM, Vissink A, den Hartog I HuddlestonSLATER JJR, Meier HJA: A systematic review of the prognosis of short $(<10 \mathrm{~mm})$ dental implants placed in the partially edentulous patient. J Clin Periodontol 2011; 38: 667-676.

31. Tutak M, Smektala T, Schneider K, Golebiewska E, Sporniak-Tutak K: Short dental implants in reduced alveolar bone height: A review of the literature. Med Sci Monit 2013; 19: 1037-1042.

32. Urdaneta RA, Daher S, Leary I, Emanueo KM, Chuang SK: The survival of ultrashort locking-taper implants. Int J Oral Maxilofac Impl 2012; 27: 644-654.

33. Weng D, Jacobson Z, Tarnow D, Hurzeler MB, Faehen O, Sanavi $F$, ÉS MTSAI: Multicenter prospectiv clinical trial of $3 i$ machined surface implants: result after 6 years of follow-up. Int J Oral Maxillofac Impl 2003; 18: 417-423.

\section{VAJDOVICH I, OROSZ M}

\section{Experiences of application of short dental implants in literature}

According to the literature short dental implants have often been used for the replacement of teeth in the daily praxis. The implantation of short dental implants raise a lot of questions. The autors's aim is to collect the most important experiences of current literature on the mentioned theme to oral implantologists. In the article 33 reviews and clinical studies have been overviewed.

The analysis of the different studies suggest that the use of short implants - taking into account of indications and contraindications - decreases the incidence of complications and the patient's discomfort as well as the cost of treatment. The use of short dental implants is proposed as an alternative method in the daily dental praxis.

Keywords: short implant, indication, contraindication, basic principles 